\title{
Energy Efficiency: The Implementation of Minimum Energy Performance Standard (MEPS) Application on Home Appliances for Residential
}

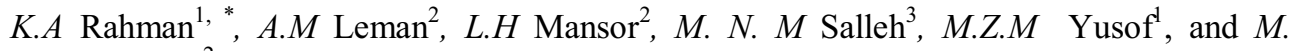 \\ Mahathir S.S ${ }^{2}$ \\ ${ }^{1}$ Faculty of Mechanical \& Manufacturing Engineering, Universiti Tun Hussein Onn Malaysia, 86400 \\ Batu Pahat, Johor, Malaysia \\ ${ }^{2}$ Faculty of Engineering Technology, Universiti Tun Hussein Onn Malaysia, 86400 Batu Pahat, Johor, \\ Malaysia \\ ${ }^{3}$ Faculty of Computer Science \& Information Technology, Universiti Tun Hussein Onn \\ Malaysia,86400 Batu Pahat, Johor, Malaysia
}

\begin{abstract}
Generally, Minimum Energy Performance Standard (MEPS) has been widespread across the country especially developed country. However, most consumers do not even know about the MEPS. Without sufficient knowledge, much energy have been wasted before this. The aim of this study is to review the implementation of MEPS of Asia country and to compare electricity consumption of home appliances with star rating and without star rating. In order to fulfil the objectives of the study, the equipment must be chosen correctly and must be learned properly. The home appliances that will be used also need to be chosen so that the comparison between the appliances will be matched correctly. To understand the results, the analysis was done using graphs and table. The purpose of using graph and table is to understand the comparison between appliances more clearly. The results show that home appliances with MEPS is more efficient on energy saving rather than without MEPS. This is the evidence as a method to educate a consumer on energy saving.
\end{abstract}

\section{Introduction}

The biggest contributor to high levels of $\mathrm{CO} 2$ emissions is the energy industry, which accounts for $41 \%$ of emissions, followed by the transport industry (23\%) and the manufacturing industry (20\%) in 2009 [1]. Accurate forecasting of energy consumption in a commercial building, including residential building is an important strategy in achieving the goal of reducing energy demand, as well as to improve Energy Efficiency (EE). To implement this strategy, many methods and indicators have been proposed to monitor and measure energy performance in buildings. The EE improvement is related to a costeffective measure in order to achieve sustainable energy development [2]. The most frequently tools that are used in any energy efficient and conservation program for

\footnotetext{
* Corresponding author : khairunnisa7482@gmail.com
} 
appliances are Minimum Energy Performance standards (MEPS) and energy labelling $[2,3,4,5]$. MEPS specifies the minimum level of energy performance for electrical appliances such as lighting and cooling and those electrical appliances must meet the requirement before they can be offered for sale or used for commercial purposes [7]. MEPS are an effective way to increase the EE of products [8]. MEPS constitute the most costeffective policy option to transform markets toward more energy efficient products. When effectively applied, in the context of an integrated policy approach, MEPS encourage manufacturers to improve the efficiency of their products [9].

Most of electricity bills soaring for a house nowadays due to the wastage of electricity. This is because consumers did not know how to use it efficiently. Generally, most houses use old electrical appliances and most of these appliances do not have energy star rating MEPS. This is because electrical appliances with star rating a bit costly compared with electrical appliances without star rating. Although electrical appliances with MEPS a bit expensive, it is better for a long term where it is similar with high electric bills that paid every month. The purpose of this research is to test EE on MEPS application that can help us in determining the efficiency of energy on electrical appliances especially on home application. Furthermore, the comparison also will be made between the home appliance with a star rating and without a star rating to help consumers make a choice wisely. In addition, consumers can calculate by its own to differentiate which one is better whether buy the home appliances with MEPS with high price and can save the electricity for a long term or vice versa. Besides, the EE knowledge can be used for practice in order for reducing the cost of electricity especially for residential bulding.

\section{Literature Review}

\subsection{Minimum Energy Performance Standards (MEPS)}

Accurate forecasting of energy consumption in a commercial building is an important strategy to achieve the goal of reducing energy demand, as well as to improve EE. To implement this strategy, many methods and indicators have been proposed to monitor and measure energy performance in buildings. EE standards and labelling has been introduced to bring more benefit for the most major classes especially for consumers [9]. Although EE standards and labelling are now commonly used around the world, the MEPS approach still not implemented widely. However, in recent years, it become among the popular strategy to be implemented in order to improve EE. Malaysia become one of the developing country to adopt this approach. MEPS are incorporated in the amendments of the Electricity Regulations 1994 and has been gazetted by the Minister of Energy, Green Technology and Water Malaysia on 3rd May 2013. Before MEPS, a Voluntary Energy Efficient Appliances and Equipment standards and labelling program for Energy Efficient Appliances and Equipment was conducted from 2009 to 2012 [10]. Currently, MEPS only implemented to five domestic electrical products which is air conditioner, refrigerator, television, fan and lighting. Mahlia et. $\mathrm{Al}$ [11] proposed to introduce labels to convince consumers to buy EE appliances. At the same time also influence the manufacturers to produce more EE products into the market.

MEPS used to determine the minimum level of energy performance that electrical appliances must meet before they can be offered for sale or used for commercial purposes [12]. The function of MEPS is to protect the consumers from products that have low energy performance [13]. The efficiency level is shown by using the star rating label. This label must be affixed onto the electrical appliances before it can be sold in the market [10]. 
Based on Electricity Regulation 1994 (Amendments 2013) Regulation 101A (3) stated, "Any equipment that meets all the requirements of efficient use of electricity under sub regulation (1) shall be affixed with an efficiency rating label in such form and manner as may be determined by the Commission." Figure 1 shows the EE label specification including energy rating, appliance type, appliance energy rating, information on brand and model, energy consumption (in $\mathrm{kWh} /$ year) and testing standards used.

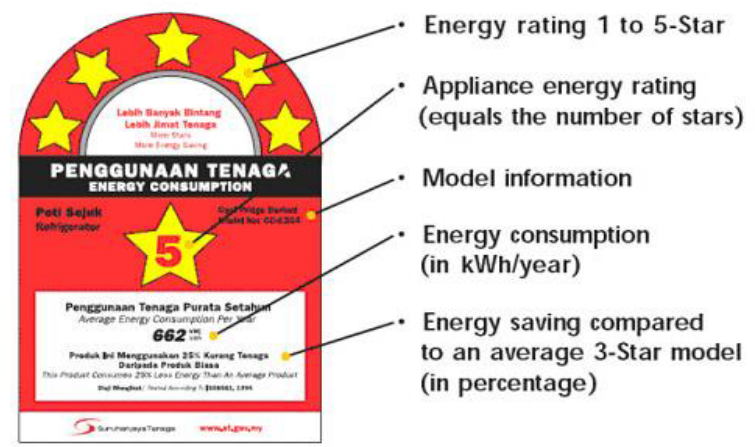

Fig. 1. The Energy Efficiency Label Specification by the Energy Commission.

\subsection{Minimum Energy Performance Standards in Malaysia}

Malaysia already has been implemented MEPS for selected electrical appliances (five appliances). Different types of electrical application will use a different method. The label verification of the implementation of the EE in Malaysia was conducted voluntarily by the Energy Commission that is operated through Ministry of Energy, Green Technologies and Water (KeTTHA) to amend the Electricity Supply Regulations 1994.

\subsubsection{Implementation of MEPS in Asian Countries}

Most of Asian countries have implemented MEPS for household appliances, equipment and lighting including Singapore, Indonesia, China and South Korea [8]. China is the most numerous target products with EE standards with around 26 target products, followed by South Korea and Japan, where both countries have the same target products that is 21 target products.

The development of MEPS for several numbers of products was handled by The Energy Commission in the Ministry of Economic Affairs (MOEA). In most cases, the energy testing were more details on Chinese Taipei for the Chinese National Standard (CNS) where the MEPS requirements are published by the MOEA. Chinese Taipei had introduced the usage of the MEPS application for the water chillers in January 2003 and was continued for the second phase in January 2005 [14]. Mahlia et. al [15] had conducted a study about the energy savings potential in Malaysia. The study indicates that implements the EE standards for room air conditioners and household refrigerators-freezers will increase the energy saving potential. There are also several research were conducted on electric motor on EE standards [16,17]. In China, EE standards for central air-conditioners and refrigerators-freezers were reported by $[9,10]$ on the potential energy savings and environmental benefits. A comprehensive guidebook on Global Standards and Labels for appliances were developed by [13]. It contains the details of the standards, labels and test procedure for appliances in residential, commercial and industrial sectors. 


\subsubsection{Tariff for Tenaga Nasional Berhad (TNB) Malaysia}

Tariff divided into a few sections such as a tariff for industrial, commercial and others. Every tariff has a different value and category. Table 1 shows electricity tariff in 2014 for domestic consumer. The tariff is used in calculating the monthly electricity to estimate the electricity consumption.

Table 1. Electricity Tariff in Malaysia.

\begin{tabular}{|l|c|c|}
\hline Tariff Category & Unit & $\begin{array}{c}\text { Current Rate (MYR) } \\
\text { (effective } \mathbf{1}^{\text {st }} \text { Jan } \\
\text { 2014) }\end{array}$ \\
\hline Tariff A - Domestic Tariff \\
\hline For the first 200 kWh $(1-200 \mathrm{kWh})$ per month & cent $/ \mathrm{kWh}$ & 21.80 \\
\hline $\begin{array}{l}\text { For the next } 100 \mathrm{kWh}(201-300 \mathrm{kWh}) \text { per } \\
\text { month }\end{array}$ & cent $/ \mathrm{kWh}$ & 33.40 \\
\hline $\begin{array}{l}\text { For the next } 300 \mathrm{kWh}(301-600 \mathrm{kWh}) \text { per } \\
\text { month }\end{array}$ & cent $/ \mathrm{kWh}$ & 51.60 \\
\hline $\begin{array}{l}\text { For the next } 300 \mathrm{kWh}(601-900 \mathrm{kWh}) \text { per } \\
\text { month }\end{array}$ & cent $/ \mathrm{kWh}$ & 54.60 \\
\hline For the next kWh $(901 \mathrm{kWh}$ onwards) per month & cent $/ \mathrm{kWh}$ & 57.10 \\
\hline$*$ The minimum monthly charge is MYR3.00 \\
\hline
\end{tabular}

\section{Methodology}

A few selections of electrical items that are refrigerators, air conditioner system, fans, electric lamp and television are selected to review and analyze the advantages of using MEPS. The criteria taken into account in this selection are the electrical goods which have MEPS and basic electrical items commonly used at home. The equation 1 below shows the calculation star index for refrigerator. Equation 2 shows how to obtain Energy Efficiency Factor (EEF) value and equation 3 and 4 shows EEF average for one door and two door refrigerator.

$$
\text { STAR Index }=\left(\frac{\mathrm{EEF}_{\text {tested }}}{\mathrm{EEF}_{\text {average }}}-1\right) \times 100 \%
$$

Where,

$$
\begin{gathered}
\text { Energy Efficiency Factor }(E E F)=\frac{\text { Adjusted Volume }(\text { litre })}{\text { Energy consumed per day }(\mathrm{kWh})} \\
E E F_{\text {average }(1 \text { door })}=1.37 V_{\text {adj }}-63.3 \\
E E F_{\text {average }(2 \text { door })}=0.409 V_{\text {adj }}+119.5
\end{gathered}
$$

Similar to the refrigerator calculation, equation 5 below shows how to determine star index for television. The different calculation showed in equation 6 that is to find the EEF value and equation 7 to calculate Annual Energy Consumption.

$$
\text { STARindex }=\left(\frac{E E F_{\text {tested }}}{E_{\text {Everage }}}-1\right) \times 100 \%
$$




$$
\text { Energy Efficiency Factor }(E E F)=\frac{\text { Screen Area }\left(\mathrm{cm}^{2}\right)}{\text { Annual Energy Consumption }(\mathrm{kWh})}
$$

Annual Energy Consumption $(k W h)=0.365\left[\left(P_{o n} \times 5\right)+P_{p s}\left(19-T_{a s}\right)+\left(P_{a s} \times T_{a s}\right)\right]$

Where,

$P_{\text {on }}=$ Power at on mode $(W)$

$P_{a s}=$ Power at active stanby mode $(W)$

$P_{p s}=$ Power at passive stanby mode

$T_{a s}=$ Time on active standby mode(hour)

EEF Average determined as $y=0.002 x+11$

The air conditioner has two cases that are non-inverter air conditioner and inverter airconditioner. Equation 8 shows the calculation to find EER value for non-inverter conditioner while equation 9 shows the calculation weighted EER for inverter air conditioner.

For non-inverter air conditioner,

$$
E R=\frac{\text { Cooling Capacity }(B t u / h)}{\operatorname{Input} \operatorname{Power}(W)}
$$

For inverter air conditioner,

Weighted EE $=\left(0.4 \times \frac{100 \% \text { Load Cooling Capacity }}{100 \% \text { Load Power Input }}\right)+\left(0.6 \times \frac{50 \% \text { Load Cooling Capacity }}{50 \% \text { Load Power Input }}\right)$

There is a single calculation for the fan, which is Coefficient of Performance (COP). This equation used to measure the ratio of air deliver and the input power. Equation 10 shows the formula of COP.

$$
\text { Coefficient of Performance }(C O P)=\frac{\text { Measured Air Deliver }\left(\frac{\mathrm{m}^{3}}{\mathrm{~min}}\right)}{\text { Input Power }(W)}
$$

\section{Result And Discussion}

\subsection{Refrigerator Analysis}

The analysis has been done on several types of refrigerator: 200-299 litres, 300-399 litres and 400-499 litres in three conditions of refrigerator with inverter and MEPS, refrigerator with inverter only and refrigerator without inverter and MEPS. Figure 2(a) shows the energy consumption for refrigerator with capacity 200-299 litres, the highest energy consumption per year is refrigerator without inverter and MEPS which is $445 \mathrm{kWh} / \mathrm{yr}$ followed by refrigerator with MEPS only $318 \mathrm{kWh} / \mathrm{yr}$ while the lowest energy consumption is refrigerator with an inverter and MEPS which is $263 \mathrm{kWh} / \mathrm{yr}$. 

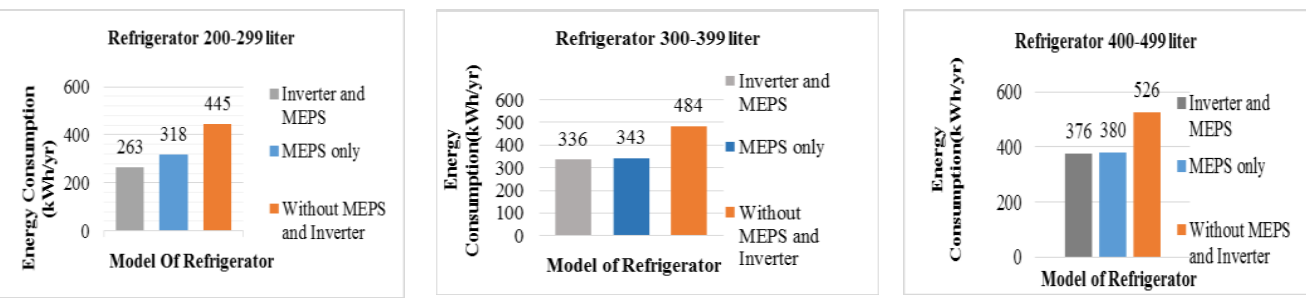

Fig. 2. Refrigerator (a) 200-299 litres, (b) 300-399 litres, (c) Refrigerator 400-499 litres.

Figure 2 (b) shows the energy consumption for refrigerator with capacity 300-399 litre, the highest energy consumption per year is refrigerator without inverter and MEPS which is $484 \mathrm{kWh} / \mathrm{yr}$ followed by refrigerator with MEPS only which is $343 \mathrm{kWh} / \mathrm{yr}$. The lowest energy consumption is refrigerator with inverter and MEPS which is $336 \mathrm{kWh} / \mathrm{yr}$. Figure 2(c) shows the energy consumption for refrigerator with capacity 400-499 litre, the highest energy consumption per year is refrigerator without inverter and MEPS which is 526 $\mathrm{kWh} / \mathrm{yr}$ followed by refrigerator with MEPS only which is $380 \mathrm{kWh} / \mathrm{yr}$ and the lowest energy consumption is refrigerator with an inverter and MEPS which is $376 \mathrm{kWh} / \mathrm{yr}$. Results show that the use of refrigerator with inverter and MEPS is more effective to reduce energy consumption in residential.

\subsection{Air Conditioner Analysis}

Analysis of the air conditioner is divided into two types that is air conditioner with 1 Horsepower (HP) and air conditioner with 1.5 Horsepower (HP). Each air conditioner is divided into three types, which is air conditioner with inverter and MEPS, MEPS only and without both the inverter and MEPS. For air conditioner analysis, it divided into two types which is air conditioner with 1 Horsepower (HP) and 1.5 Horsepower (HP). Figure 4(a) shows the energy consumption for air conditioner with 1 Horsepower (HP), the highest energy consumption per year is air conditioner without inverter and MEPS which is 3024 $\mathrm{kWh} / \mathrm{yr}$ followed by air conditioner with MEPS only which is $2292 \mathrm{kWh} / \mathrm{yr}$. The lowest energy consumption per year is air conditioner with both inverter and MEPS which is 1562 $\mathrm{kWh} / \mathrm{yr}$. Figure $4(\mathrm{~b})$ is for air conditioner with 1.5 Horsepower (HP), the higher energy consumption per year is air conditioner without inverter and MEPS which is $4630 \mathrm{kWh} / \mathrm{yr}$ followed by air conditioner with MEPS only which is $3419 \mathrm{kWh} / \mathrm{yr}$. The lowest energy consumption per year is air conditioner with both inverter and MEPS which is 1935 $\mathrm{kWh} / \mathrm{yr}$.
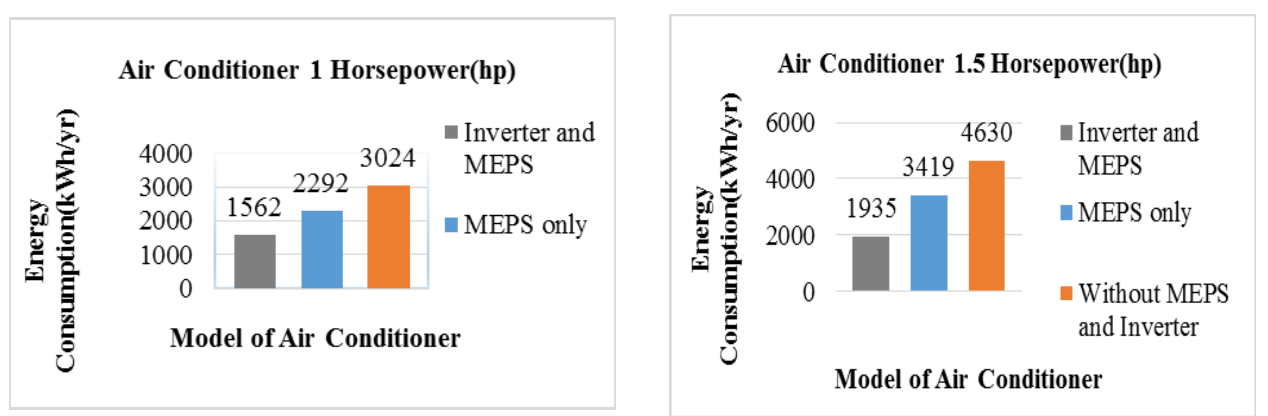

Fig. 4. Energy Consumption for Air Conditioner, (a) 1 Horsepower (HP), (b) 1.5 Horsepower (HP). 


\subsection{Fan Analysis}

Analysis of the fan is divided into two types fan that is table fan and stand fan. Each fan is divided into two types, which is fan with MEPS and fan without MEPS. For analysis of fan also divided into two types which is stand fan and table fan. Figure 5(a) shows the energy consumption for stand fan, the highest energy consumption per year is stand fan without MEPS which is $158 \mathrm{kWh} / \mathrm{yr}$ and the lowest energy consumption per year is stand fan with MEPS which is $132 \mathrm{kWh} / \mathrm{yr}$. Figure 5(b) shows the energy consumption for table fan. The highest energy consumption per year is stand fan without MEPS which is $175 \mathrm{kWh} / \mathrm{yr}$ and the lowest energy consumption per year is stand fan with MEPS which is $146 \mathrm{kWh} / \mathrm{yr}$.
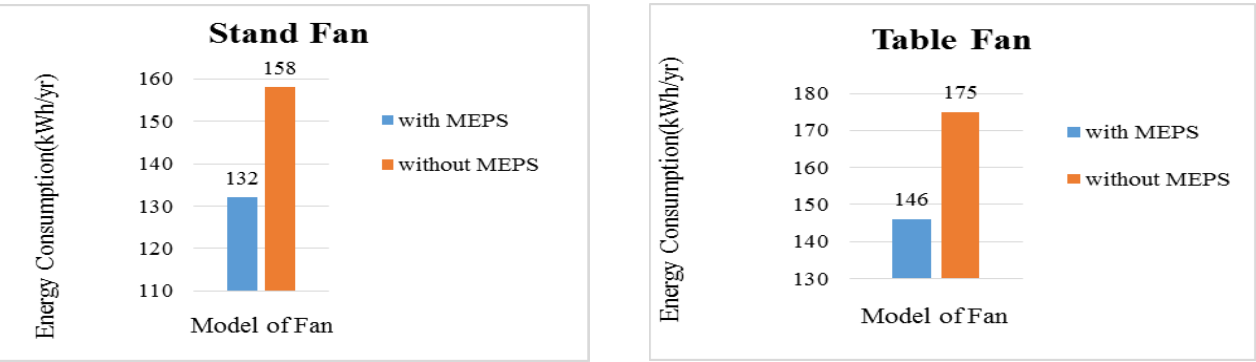

Fig. 5. Energy Consumption, (a) Stand Fan, (b) Table Fan.

\subsection{Lamp Analysis}

Analysis for the lamp is divided into three types such as fluorescent lamp, energy saving lamp and Light Emitting Diode (LED) lamp. Fluorescent lamp and energy saving lamp used 18 Watts of power while LED lamp only used 9 Watts of energy. The brightness for all three types of lamps are almost the same. In addition, LED lamp are brighter even though only use energy 9 Watts. For lamp analysis, it is divided into three types which is LED lamp, energy saving lamp and fluorescent lamp. Based on Figure 6, the highest energy consumption per year is fluorescent lamp which is $569.4 \mathrm{kWh} / \mathrm{yr}$ followed by the moderate is $551.2 \mathrm{kWh} / \mathrm{yr}$. The lowest energy consumption per year is LED is $511 \mathrm{kWh} / \mathrm{yr}$.

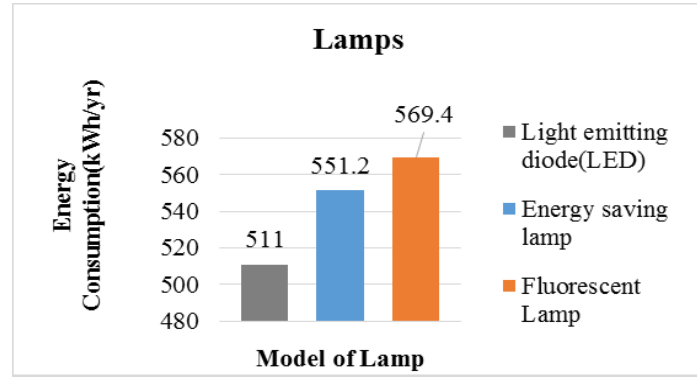

Fig. 6. Energy Consumption for Lamps.

\subsection{Television Analysis}

Analysis of television is divided into three types which is Liquid Crystal Display (LCD), plasma and LED. Each types of television is divided into two types which is with and without MEPS. For analysis of television, it is divided into three types which is LCD 
television, Plasma television and LED television. Figure 7(a) shows the results for LCD television which indicates the highest energy consumption per year LCD television is without MEPS which is $84.73 \mathrm{kWh} / \mathrm{yr}$ while the lowest is LCD television with MEPS which is $64 \mathrm{kWh} / \mathrm{yr}$.
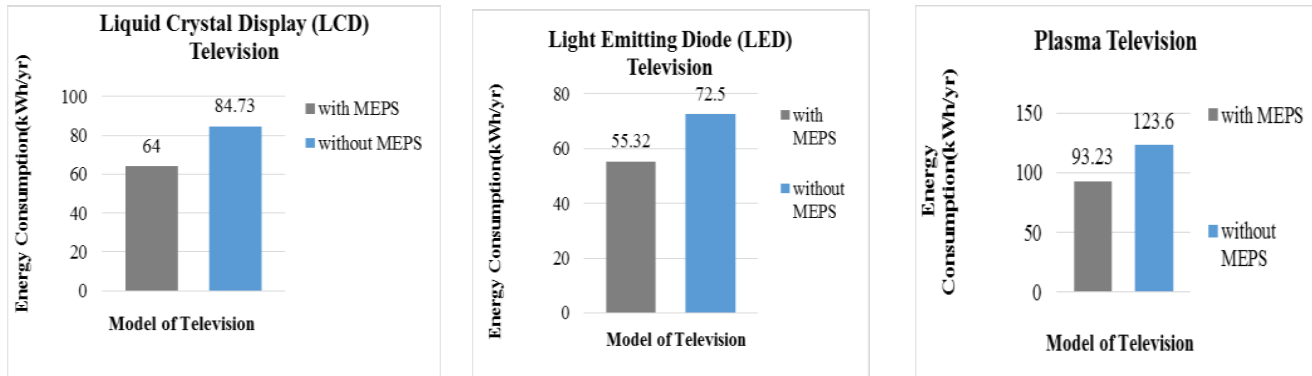

Fig. 7. (a) Liquid Crystal (LCD) TV, (b) Light Emitting Diode (LED) TV, (c) Plasma TV.

Furthermore, Figure 7(b) shows the measurement for LED television. The highest energy consumption per year is LED television without MEPS which is $72.5 \mathrm{kWh} / \mathrm{yr}$ followed by the lowest is LED television with MEPS which is $55.32 \mathrm{kWh} / \mathrm{yr}$. Figure 7(c) shows the energy consumption for plasma television. The highest energy consumption per year is plasma television without MEPS which is $123.6 \mathrm{kWh} / \mathrm{yr}$ while the lowest is LED television with MEPS which is $93.23 \mathrm{kWh} / \mathrm{yr}$. Table 2 shows the summary of all the measurements on five types of electrical appliances which using the EE approach (MEPS) and do not use it. Results show that the implementation of EE approach can reduce the energy consumption for five types of electrical appliances.

Table 2. Summary of Measurement on Five Electrical Appliances.

\begin{tabular}{|c|c|c|c|c|c|c|c|c|c|}
\hline \multirow[t]{3}{*}{ No } & \multirow{3}{*}{$\begin{array}{c}\text { Electrical } \\
\text { Appliances }\end{array}$} & \multirow{2}{*}{\multicolumn{3}{|c|}{$\begin{array}{c}\text { Types } \\
\text { kWh/yr }\end{array}$}} & \multirow[t]{3}{*}{ No } & \multirow{3}{*}{$\begin{array}{c}\text { Electrical } \\
\text { Appliances }\end{array}$} & \multirow{2}{*}{\multicolumn{3}{|c|}{$\begin{array}{c}\text { Types } \\
\text { kWh/yr }\end{array}$}} \\
\hline & & & & & & & & & \\
\hline & & $\begin{array}{c}\text { Without } \\
\text { Inverter } \\
\text { and } \\
\text { MEPS }\end{array}$ & MEPS & $\begin{array}{l}\text { Inverter } \\
\text { and } \\
\text { MEPS }\end{array}$ & & & $\begin{array}{l}\text { Without } \\
\text { MEPS }\end{array}$ & MEPS & - \\
\hline \multirow[t]{4}{*}{1} & \multicolumn{4}{|l|}{ Refrigerator } & \multirow[t]{3}{*}{3} & \multicolumn{4}{|l|}{ Fan } \\
\hline & $\begin{array}{l}200- \\
\text { 299Ltrs }\end{array}$ & 445 & 318 & 263 & & Stand Fan & 158 & 132 & - \\
\hline & $\begin{array}{l}300- \\
\text { 399Ltrs }\end{array}$ & 484 & 343 & 336 & & Table Fan & 175 & 146 & - \\
\hline & $\begin{array}{l}\text { 400- } \\
\text { 499Ltrs }\end{array}$ & 526 & 380 & 376 & 4 & Television & & & \\
\hline \multirow[t]{5}{*}{2} & \multicolumn{4}{|c|}{ Air-conditioner } & & LCD & 84.73 & 64 & - \\
\hline & \multirow[t]{2}{*}{$1.0 \mathrm{HP}$} & \multirow[t]{2}{*}{3024} & \multirow[t]{2}{*}{2292} & \multirow[t]{2}{*}{1562} & & LED & 72.5 & 55.32 & - \\
\hline & & & & & & Plasma & 123.6 & 93.23 & - \\
\hline & \multirow[t]{2}{*}{$1.5 \mathrm{HP}$} & \multirow[t]{2}{*}{4630} & \multirow[t]{2}{*}{3416} & \multirow[t]{2}{*}{1935} & 5 & Lamp & Fluorescent & $\begin{array}{l}\text { Energy } \\
\text { Saving }\end{array}$ & LED \\
\hline & & & & & & $\mathrm{kWh} / \mathrm{yr}$ & 569.4 & 551.2 & 511 \\
\hline
\end{tabular}




\section{Conclusion}

EE is doing more with less energy benefits to consumers, country, and to the global. This study has successfully shown the home electrical appliances with MEPS can save the energy consumption. MEPS application has helped us in determining the efficiency of energy on electrical appliances especially on home application. In addition, the benefits of energy efficiency are numerous. Used energy more efficiently can reduce expenses, improves the economy, protect the environment, improves national security and it will enhance the quality of life.

The authors would like to express their gratitude to the University Tun Hussein Onn Malaysia (UTHM) and the Ministry of Education Malaysia for Hadiah Latihan Persekutuan (HLP) Scholarship for the study (author 1).

\section{References}

1. http://www.iea.org

2. H. Khatib, Energy policy, 48, 737 (2012)

3. H.P. Siderius, Energy Policy, 70, 1 (2014)

4. H.P. Siderius, Energy Policy, 59, 762 (2013)

5. L. Harrington, G. Wilkenfeld, Energy and Buildings, 26, 81 (1997)

6. K.A. Rahman, M.Z.M. Yusof, M.N.M. Salleh, A.M. Leman, Engineering Technology International Conference, 2015

7. K.A. Rahman, M.Z. Yusof, M.N. Salleh, A.M. Leman, Technology and Innovation National Conference Proceedings, 2015

8. K.A Rahman, M.Z. Md Yusof, M.N. Mohd Salleh, A.M. Leman, Chem. Eng. Trans., 45, 1663 (2015)

9. X. Shi, Appl. Energy, 133, 135 (2014)

10. http://www.st.gov.my/

11. T.M.I. Mahlia, H.H. Masjuki, I.A. Choudhury, Energy Convers. Manag., 43, 743 (2002)

12. CSA-C743-02 Performance Standard for Rating Packaged Water Chillers, Canadian Standards Association, 2002

13. S. Wiel, J.E. McMahon, CLASP, 2 (2005)

14. R. Saidur, T.M.I. Mahlia, M. Hasanuzzaman, Energy Sci. Res., 27, 175 (2011)

15. T.M. Mahlia, H. Masjuki, R. Saidur, M. Amalina, Energy Policy, 32, 1819 (2004)

16. A.T. De Almeida, P. Fonseca, P. Bertoldi, Energy, 28, 673 (2003)

17. A.G.P. Garcia, A.S. Szklo, R. Schaeffer, M.A. McNeil, Energy Policy, 35, 3424 (2007)

18. W. Lu, Energy Policy, 35, 1709 (2007)

19. W. Lu, Energy Policy, 34, 1583 (2006) 